\title{
Physiological effects of proinsulin-connecting peptide in human subcutaneous adipose tissue
}

\author{
A Ghorbani $^{1}$, R Shafiee-Nick ${ }^{1,2}$, SA Zojaji ${ }^{2}$, MT Rajabi-Mashhadi ${ }^{3,4}$ \\ ${ }^{1}$ Pharmacological Research Center of Medicinal Plants, Mashhad University \\ of Medical Sciences, Mashhad, Iran \\ ${ }^{2}$ Department of Pharmacology, Faculty of Medicine, Mashhad University of Medical Sciences, Mashhad, Iran \\ ${ }^{3}$ Department of Surgery, Omid Hospital, Mashhad University of Medical Sciences, Mashhad, Iran \\ ${ }^{4}$ Endoscopic \& Minimally Invasive Surgery Research Center, Mashhad University of Medical Sciences, \\ Mashhad, Iran
}

Received: May 23, 2016

Accepted: March 6, 2017

\begin{abstract}
Recent studies suggest that proinsulin-connecting peptide (C-peptide) may exhibit characteristics of a hormone and show physiological functions in various tissues. This study was aimed to determine whether C-peptide could be involved in the regulation of lipolysis, adiponectin release, and function of mesenchymal stem cells (MSCs) in adipose tissue. Human subcutaneous adipose tissue was cultured in the presence of C-peptide. The level of lipolysis was determined by glycerol measurement in the conditioned media. Effect of C-peptide on adiponectin secretion was evaluated in differentiated adipocytes. The adipogenic and osteogenic abilities of adipose MSCs were evaluated using oil red and alizarin red staining, respectively. The tetrazolium bromide test was conducted for evaluating the effect of C-peptide on MSCs proliferation. C-peptide induced a significant decrease in basal lipolysis at concentrations of 8 and $16 \mathrm{nM}(p<0.05)$. It had no significant effects on isoproterenol-stimulated lipolysis, adiponectin secretion, and adipogenic or osteogenic differentiation of MSCs. At a concentration of $4 \mathrm{nM}$, this peptide significantly increased the proliferative capability of MSCs $(p<0.05)$. These results suggest that C-peptide has some physiological effects in human subcutaneous adipose tissue and contributes to the regulation of basal lipolysis and pool of MSCs.
\end{abstract}

Keywords: adipose tissue, adiponectin, C-peptide, stem cells, differentiation

\section{Introduction}

Proinsulin-connecting peptide (C-peptide) is a cleavage product of insulin release in the pancreatic beta cells. For a long time, it has been considered as a biologically inert byproduct of insulin synthesis, and served just as an indicator of endogenous insulin secretion in diabetic patients (6). However, recent data from several lines of studies suggest that C-peptide may exhibit characteristics of a peptide hormone and show physiological functions in various tissues $(21,53)$. It increases muscle glucose transport (46) and tissue blood flow $(25,29)$, and has cytoprotective and antiapoptotic effects (8). It is now accepted that this peptide improves the function of most organs affected by diabetes complications (e.g., kidney, heart, and nerve) and administration of C-peptide together with the classic insulin therapy may prevent, retard, or ameliorate diabetic complications in patients with type-1 diabetes $(21,52,53)$. For

\footnotetext{
Corresponding author: Ahmad Ghorbani, $\mathrm{PhD}$

Pharmacological Research Center of Medicinal Plants, Mashhad University of Medical Sciences

Pardis Campus, Azadi Square, Mashhad 9177948564, Iran

Phone: +98 5138002256; Fax: +98 5138828567; E-mail: ghorbania@mums.ac.ir
} 
example, clinical studies have shown that combination of C-peptide and insulin can ameliorate nephropathy and neuropathy in diabetic patients $(28,52)$.

Diabetic patients show a spectrum of abnormalities in lipid metabolism including increased serum lipids, uncontrolled lipolysis, and dysregulation of adipogenesis and lipogenesis in adipose tissue. These abnormalities are associated with the development of atherosclerosis and cardiovascular diseases $(4,24,34)$. In addition, there are some reports that diabetes may impair some abilities of mesenchymal stem cells (MSCs). For example, decreased mobilization ability of bone marrow MSCs and decreased wound-healing capability of adipose tissue MSCs have been demonstrated in the patients with type 1 and type 2 diabetes $(7,12)$.

Although insulin-like actions of C-peptide have been reported in some tissues, such as muscle, the effects of C-peptide on adipose tissue, the main target organ of insulin involved in lipid metabolism, are not yet well known. In our previous studies on normal and diabetic rats, we observed that this peptide may conditionally act as an antilipolytic hormone $(19,20)$. The aim of this study was to examine whether C-peptide could be involved in the regulation of lipolysis, adiponectin secretion, and proliferation and differentiation abilities of MSCs in human subcutaneous adipose tissue.

\section{Materials and Methods}

\section{Chemical compounds}

High glucose Dulbecco's Modified Eagles Medium (DMEM), fetal bovine serum (FBS), and trypsin were purchased from Gibco (Grand Island, NY, USA). Dimethyl sulfoxide (DMSO), fatty acid-free bovine serum albumin fraction $\mathrm{V}$, glycerol assay reagent, isoproterenol (ISO), human adiponectin enzyme-linked immunosorbent assay (ELISA) kit, penicillin-streptomycin solution, type-II collagenase, 3-isobutyl-1-methylxanthine, 3-(4,5dimethyl-2-thiazolyl)-2,5-diphenyl-2H-tetrazolium bromide (MTT), and 4-(2-hydroxyethyl) piperazine-1-ethanesulfonic acid sodium salt (HEPES) were obtained from Sigma-Aldrich (St. Louis, MO, USA). Human C-peptide was purchased from Bachem (Bubendorf, Switzerland). Human insulin and indomethacin were kindly provided by Exir Company, Iran. Fluorescein isothiocyanate-conjugated antibodies against CD34, CD44, CD45, and CD105 were bought from AbD Serotec (Raleigh, NC, USA).

\section{Subjects}

The subcutaneous adipose tissue samples were obtained from patients (35-55 years, body mass index less than $30 \mathrm{~kg} / \mathrm{m}^{2}$ ) undergoing conventional intra-abdominal surgery (cholecystectomy and hernia repair). Pregnant women and patients with serious diseases such as cancer, infections, and autoimmune diseases were excluded. The study protocols were reviewed and approved by the Ethics Committee of the Mashhad University of Medical Sciences. Informed written consent was obtained from each volunteer for obtaining a subcutaneous fat sample.

\section{Lipolysis study}

The effect of C-peptide on lipolysis was evaluated in ex vivo organ culture condition. The tissue samples were minced into small slices with a sterile procedure, washed with phosphatebuffered saline (PBS), and dried on the sterile gauze. Then, the tissue slices were precisely 
weighed and distributed into 24 -well plates $(100 \mathrm{mg} /$ well). For basal lipolysis assessment, the tissue slices were cultured for $24 \mathrm{~h}$ in serum-free DMEM $(1 \mathrm{ml} /$ well $)$ in the presence or absence of 4-16 $\mathrm{nM} \mathrm{C}$-peptide at $37{ }^{\circ} \mathrm{C}$ in an atmosphere of $5 \% \mathrm{CO}_{2}$. For stimulated lipolysis assessment, the tissue slices were distributed into a 24-well plate $(100 \mathrm{mg} /$ well $)$ containing $1 \mathrm{ml} /$ well Krebs-Ringer bicarbonate buffer $(118 \mathrm{mM} \mathrm{NaCl}, 4.8 \mathrm{mM} \mathrm{KCl}, 1.3 \mathrm{mM} \mathrm{CaCl}$, $1.2 \mathrm{mM} \mathrm{MgSO}_{4}, 1.2 \mathrm{mM} \mathrm{KH}_{2} \mathrm{PO}_{4}$, and $10 \mathrm{mM} \mathrm{NaHCO}_{3}$ ) supplemented with $5.5 \mathrm{mM}$ glucose, $25 \mathrm{mM}$ HEPES, and $2 \%$ (w/v) bovine serum albumin (16). Then, the tissues were treated for $90 \mathrm{~min}$ with $1 \mu \mathrm{M}$ ISO (a non-selective beta-adrenergic receptor agonist) and 4-16 nM C-peptide under constant shaking at $37^{\circ} \mathrm{C}$. The level of lipolysis was determined by measurement of glycerol in the conditioned media using glycerol assay reagent based on an enzymatic method.

\section{Isolation and characterization of MSCs}

Adipose tissue samples were minced into small slices, washed with PBS, and incubated in PBS containing collagenase $(2 \mathrm{mg} / \mathrm{ml})$ under constant shaking at $37{ }^{\circ} \mathrm{C}(17)$. After $90 \mathrm{~min}$, the digested tissues were centrifuged for $5 \mathrm{~min}$ at 2,000 rpm and the floated lipid layer was discarded. The precipitated stromal cells were washed with PBS and then cultured in $25-\mathrm{cm}^{2}$ flasks containing DMEM supplemented with $10 \% \mathrm{FBS}, 100 \mu \mathrm{g} / \mathrm{ml}$ streptomycin, and $100 \mathrm{IU} / \mathrm{ml}$ penicillin. After $24 \mathrm{~h}$, non-adherent cells were discarded and anchored cells were expanded over three passages. To confirm MSC phenotype of isolated cells, they were incubated with antibodies against cell surface antigens CD34, CD44, CD45, and CD105 for 30 min at $4{ }^{\circ} \mathrm{C}$. After washing with PBS, the cells were suspended in PBS supplemented with $2 \%$ FBS and then flow cytometric analysis was performed using an FACSCalibur (BD Biosciences, San Jose, USA) flow cytometer.

\section{Cell proliferation assay}

The effect of C-peptide on the proliferation of MSCs was evaluated using MTT assay. The cells from passage 3 were seeded in 96-well culture plates $\left(5 \times 10^{3}\right.$ cells/well $)$ in DMEM supplemented with $100 \mu \mathrm{g} / \mathrm{ml}$ streptomycin, $100 \mathrm{IU} / \mathrm{ml}$ penicillin, and $10 \% \mathrm{FBS}$. After $24 \mathrm{~h}$, the culture media was changed by a fresh one containing 1-64 nM C-peptide. The cells were incubated for either $24 \mathrm{~h}$ or $48 \mathrm{~h}$ at $37^{\circ} \mathrm{C}$ in an atmosphere of $5 \% \mathrm{CO}_{2}$. Then, MTT was added to the media at a final concentration of $0.5 \mathrm{mg} / \mathrm{ml}$. After $3 \mathrm{~h}$, the media was discarded and the precipitated formazan dye was dissolved in DMSO. The absorbance of the dye was measured at $545 \mathrm{~nm}$ using a StatFax303 plate reader.

\section{Adipogenic differentiation assay}

The MSCs at passage 3 were seeded in 12-well plates $\left(5 \times 10^{4}\right.$ cells per well $)$ and cultured for $24 \mathrm{~h}$ in DMEM supplemented with $10 \% \mathrm{FBS}, 100 \mu \mathrm{g} / \mathrm{ml}$ streptomycin, and $100 \mathrm{IU} / \mathrm{ml}$ penicillin. Then, for adipogenic induction, the cells were incubated with the differentiation medium consisting of DMEM supplemented with $3 \% \mathrm{FBS}, 5 \mu \mathrm{M}$ indomethacin, and $1 \mu \mathrm{M}$ dexamethasone, in either the presence or absence of $0.2 \mu \mathrm{M}$ insulin or $16 \mathrm{nM}$ C-peptide. The cells were maintained in adipogenic medium for 12 days; meanwhile, the medium was replaced every 3 days. Then, the cells were fixed with $10 \%$ formalin and stained with oil red $\mathrm{O}$ dye, which stains intracellular triglycerides in differentiated adipocytes. After washing thrice with PBS, $200 \mu$ isopropanol was added to each well to elute the stain from cells and its optical density was measured at $545 \mathrm{~nm}(2)$. 
Osteogenic differentiation assay

The MSCs at passage 3 were seeded in 12 -well plates $\left(5 \times 10^{4}\right.$ cells per well $)$ and cultured for $24 \mathrm{~h}$ in DMEM supplemented with antibiotics and 10\% FBS. For osteogenic induction, the cells were further cultured in a differentiation medium consisting of DMEM supplemented with $10 \% \mathrm{FBS}, 10 \mu \mathrm{g} / \mathrm{ml}$ ascorbic acid, $5 \mathrm{mM} \beta$-glycerol phosphate, and $0.1 \mu \mathrm{M}$ dexamethasone in the presence or absence of 4-16 nM C-peptide. The cells were maintained in the osteogenic medium for 2 weeks and the medium was replaced every 3 days. Then, the cells were fixed with formalin and stained with alizarin red dye which stains calcium-rich mineral deposits excreted by differentiated cells. After washing the wells thrice with PBS, $400 \mu 10.5 \mathrm{~N} \mathrm{HCl}-5 \%$ sodium dodecyl sulfate solution was added to each well to solubilize the stain and its optical density was measured at $405 \mathrm{~nm}(3)$.

\section{Adiponectin release assay}

The effect of C-peptide on adiponectin secretion was evaluated in differentiated adipocytes. Initially, MSCs were seeded in 6 -well plates $\left(1 \times 10^{5}\right.$ cells/well $)$ and differentiated into adipocytes as described above. Then, the differentiated adipocytes were incubated in serum-free DMEM containing 4, 8, or $16 \mathrm{nM}$ of C-peptide for $24 \mathrm{~h}$ at $37{ }^{\circ} \mathrm{C}$ in an atmosphere of $5 \% \mathrm{CO}_{2}$. The level of adiponectin in condition media was measured with ELISA method.

\section{Statistical analysis}

Data were analyzed by one-way analysis of variance, followed by Tukey's post hoc test. The results were presented as mean \pm standard error of mean (SEM). They were considered to be statistically significant when $p$ values were less than 0.05 .

\section{Results}

Effect of C-peptide on lipolysis

Table I demonstrates the effect of C-peptide on adipose tissue lipolysis. The presence of 8 and $16 \mathrm{nM}$ of C-peptide in the culture medium reduced the level of lipolysis to $83 \% \pm 6 \%$ and $83 \% \pm 4 \%$ of the basal level, respectively $(p<0.05)$. Regarding stimulated lipolysis, ISO $(1 \mu \mathrm{M})$ led to a significant elevation in lipolysis $(p<0.01)$ as expected. C-peptide at the tested concentrations had no significant effect on ISO-stimulated lipolysis.

\section{Characterization of MSCs}

Flow cytometric analysis showed that the MSCs isolated in this work were positive for stem cell-associated markers CD44 and CD105, and consistently negative for hematopoietic markers CD34 and CD45.

\section{Effect of C-peptide on MSCs proliferation}

As shown in Fig. 1A, incubation with $4 \mathrm{nM} \mathrm{C}$-peptide for $24 \mathrm{~h}$ significantly increased proliferation of MSCs compared with untreated cells $(136 \% \pm 13 \%$ vs. $100 \% \pm 3 \%$, $p<0.05)$. Similarly, after $48 \mathrm{~h}$ incubation, C-peptide could significantly $(12 \%, p<0.05)$ enhance proliferation of MSCs only at a concentration of $4 \mathrm{nM}$ (Fig. 1B). 
Table I. Effects of C-peptide on basal and stimulated lipolysis in human subcutaneous adipose tissue

\begin{tabular}{|l|l|c|}
\hline & \multicolumn{1}{|c|}{ Treatment } & Relative lipolysis (\%) \\
\hline \multirow{2}{*}{ Basal lipolysis } & Control & $100 \pm 3$ \\
& C-peptide $(4 \mathrm{nM})$ & $98 \pm 6$ \\
& C-peptide $(8 \mathrm{nM})$ & $83 \pm 4^{*}$ \\
& C-peptide $(16 \mathrm{nM})$ & $83 \pm 3^{*}$ \\
\hline \multirow{2}{*}{ Stimulated lipolysis } & Control & $100 \pm 5$ \\
& ISO $(1 \mu \mathrm{M})$ & $327 \pm 54^{* *}$ \\
& ISO $(1 \mu \mathrm{M})+$ C-peptide $(4 \mathrm{nM})$ & $303 \pm 50^{*}$ \\
& ISO $(1 \mu \mathrm{M})+$ C-peptide $(8 \mathrm{nM})$ & $304 \pm 54^{*}$ \\
& ISO $(1 \mu \mathrm{M})+$ C-peptide $(16 \mathrm{nM})$ & $267 \pm 47$ \\
\hline
\end{tabular}

Basal lipolysis: adipose tissue slices were cultured for $24 \mathrm{~h}$ in serum-free DMEM in the presence of C-peptide. ${ }^{*} p<0.05$ vs. untreated cells. Stimulated lipolysis: the tissue slices were maintained in Krebs-Ringer bicarbonate buffer and treated for 90 min with $1 \mu \mathrm{M}$ ISO or human C-peptide. ${ }^{*} p<0.05$ vs. control; $* * p<0.01$ vs. control

A

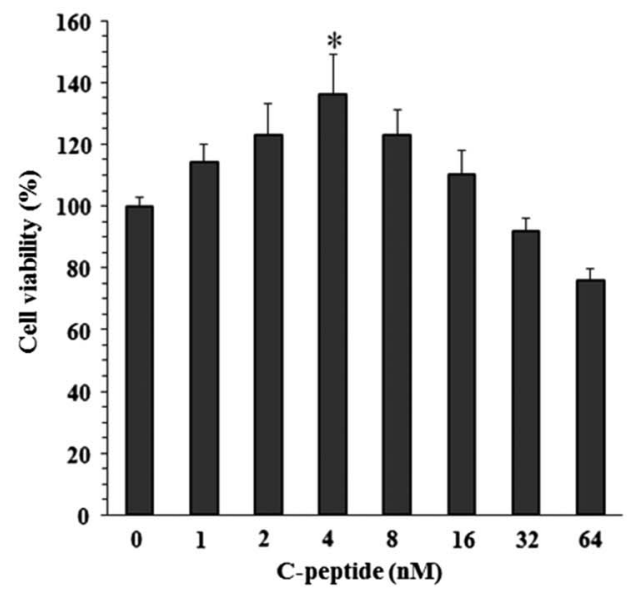

B

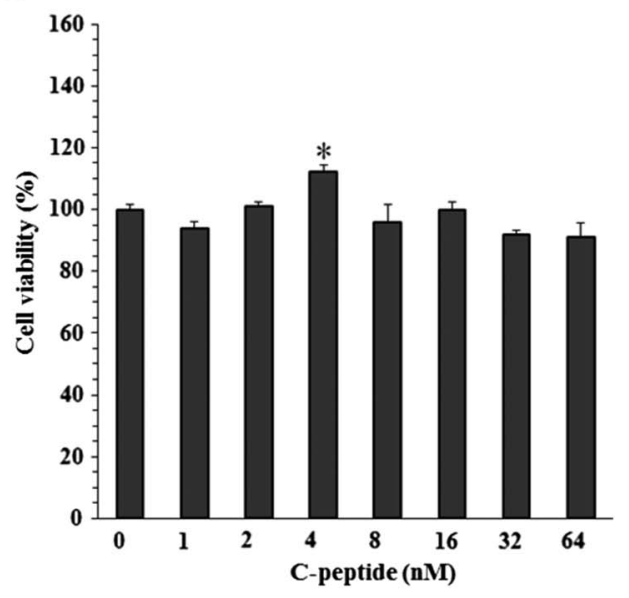

Fig. 1. Effect of C-peptide on the proliferation of MSCs isolated from human subcutaneous adipose tissue. The MSCs were treated for either $24 \mathrm{~h}$ (A) or $48 \mathrm{~h}$ (B) with human C-peptide and then MTT assay was performed. Data are represented by means \pm SEM of three independent experiments performed in triplicate. ${ }^{*} p<0.05$ vs. untreated cells (concentration of 0 )

\section{Effects of C-peptide on MSCs differentiation}

Figure 2 shows the effect of C-peptide on osteogenic differentiation of MSCs. Incubation of the differentiating cells with C-peptide concentrations of 4, 8, and $16 \mathrm{nM}$ had no effect on osteogenesis as evaluated with alizarin red staining of the extracellular calcium deposit. Figure 3 demonstrates the effect of insulin and C-peptide on adipogenic differentiation of MSCs. The addition of insulin to the differentiation medium promoted the accumulation of intracellular lipid droplets. On the other hand, C-peptide at the tested concentration (16 nM) failed to induce adipogenic differentiation of MSCs. It also failed to enhance the stimulatory effect of insulin on intracellular lipid droplet accumulation. 


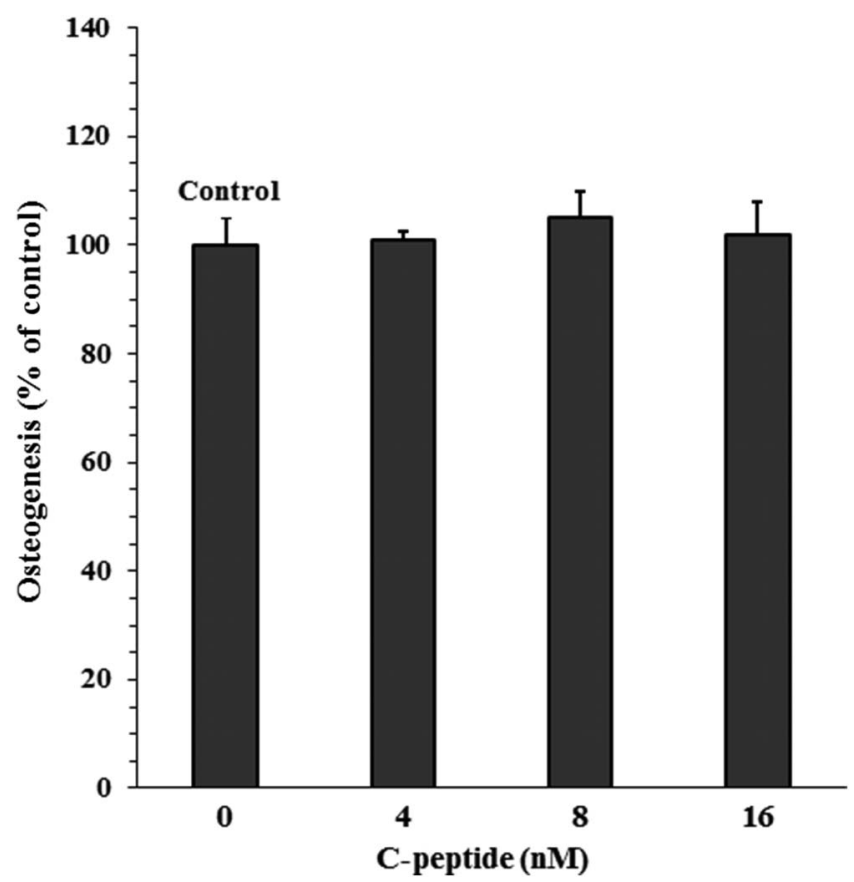

Fig. 2. Effect of C-peptide on osteogenic differentiation of MSCs isolated from human subcutaneous adipose tissue. The MSCs were maintained in osteogenic medium for 2 weeks in the presence of C-peptide and the level of differentiation was quantified by measuring the optical density of alizarin red which stains calcium deposits

\section{Effect of C-peptide on adiponectin release}

The effect of C-peptide on adiponectin secretion from differentiated adipocytes is shown in Fig. 4. In the presence of 4,8 , and $16 \mathrm{nM}$ of this peptide, concentrations of adiponectin in culture media were $11 \pm 2 \mathrm{ng} / \mathrm{ml}, 9.8 \pm 2 \mathrm{ng} / \mathrm{ml}$, and $8.7 \pm 2.5 \mathrm{ng} / \mathrm{ml}$, respectively, which were not statistically different from the value measured in the medium of untreated cells $(8.3 \pm 2.5 \mathrm{ng} / \mathrm{ml})$.

\section{Discussion}

This is the first study to show that C-peptide decreases lipolysis and increases proliferation of MSCs in human adipose tissue. These results rule out the earlier view that that C-peptide is biologically inert and supports the current suggestion that it not only plays an important role in the synthesis of insulin but also acts as a peptide hormone.

The adipose tissue is one of the largest compartments in the body and has many physiological functions including energy storage and hormone secretion $(1,32)$. During times of energy excess, it accumulates triglyceride through lipogenesis and adipogenesis processes, and during calory insufficiency, it delivers the stored triglyceride through the activation of lipolysis (10). This tissue is one of the main target organs of insulin, where it stimulates lipogenesis and adipogenesis, and inhibits lipolysis $(18,21,31,35,45)$. Lipolysis is under the control of the endocrine and the nervous systems. Catecholamines stimulate lipolysis through beta-adrenergic receptors, which enhance adenylate cyclase activity, and raise intracellular production of cyclic adenosine monophosphate (cAMP). The increased cAMP results in activation of protein kinase $A$ and subsequent activation of hormone sensitive lipase. On the other hand, insulin inhibits lipolysis by activating the phosphodiesterase-3B and consequently 

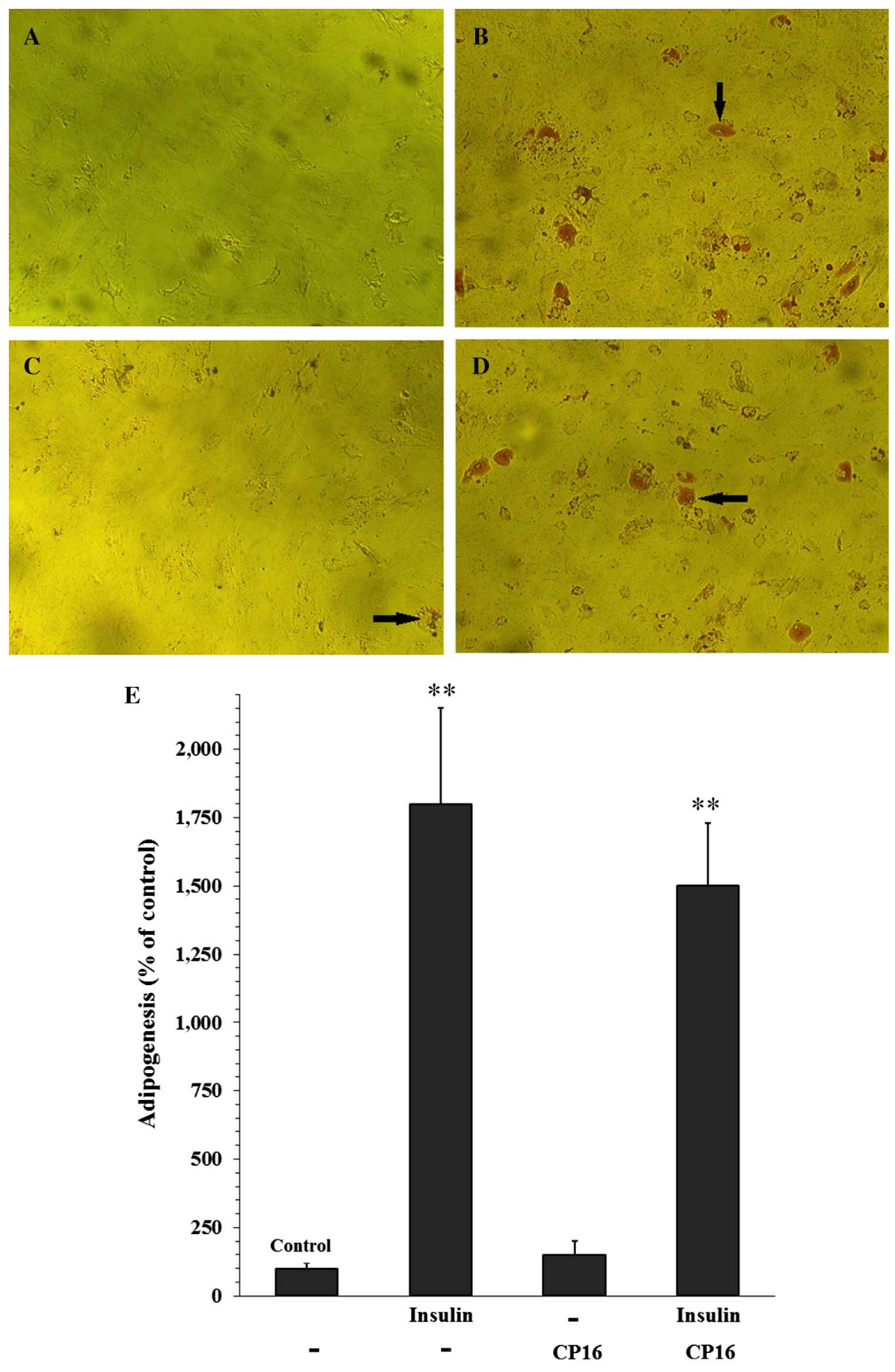

Fig. 3. Effect of C-peptide on adipogenic differentiation of MSCs isolated from human subcutaneous adipose tissue. The MSCs were maintained in adipogenic medium (consisting of DMEM supplemented with 3\% FBS, $5 \mu \mathrm{M}$ indomethacin, and $1 \mu \mathrm{M}$ dexamethasone) for 12 days either in the absence (A) or presence of $0.2 \mu \mathrm{M}$ insulin (B), $16 \mathrm{nM}$ C-peptide (C), or both insulin and C-peptide (D). The lipid accumulation was quantified by measuring the optical density of oil red O stain eluted from cells (E). Data are represented by means \pm SEM $(n=3)$. $* * p<0.01$ vs. control. Black arrow: oil red O stained intracellular lipid droplets; CP16: 16 nM C-peptide 


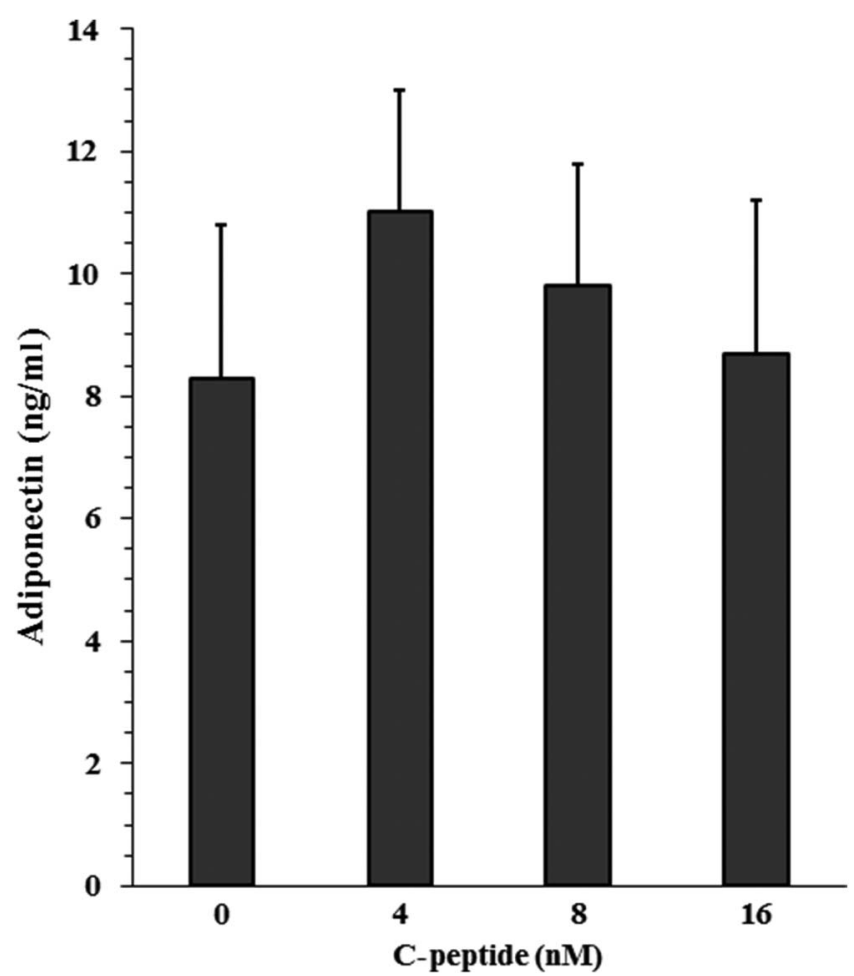

Fig. 4. Effect of C-peptide on the secretion of adiponectin from differentiated adipocytes. The subcutaneous adipocytes were incubated $24 \mathrm{~h}$ in a serum-free medium containing C-peptide and the level of adiponectin in condition media was measured with ELISA method. Data are represented by means \pm SEM of two independent experiments performed in triplicate

reduces cAMP level (35). This data showed that C-peptide, at concentrations of 8 and $16 \mathrm{nM}$, decreases lipolysis in the basal state and therefore possesses insulin-like action on lipolysis. This effect is most probably mediated by activating phosphodiesterase-3B in adipocytes (20). Insulin deficiency as seen in type-1 diabetes is associated with increased lipolysis that ultimately results in severing fat loss and even diabetic ketoacidosis $(22,43)$. Because of the antilipolytic property of C-peptide, coreplacement of insulin and C-peptide may prevent, retard, or ameliorate such diabetes-related complications.

In our previous works on the visceral adipose tissue of normal rats, the inhibitory effect of C-peptide $(6 \mathrm{nM})$ on basal lipolysis remained non-significant after $90 \mathrm{~min}$ of incubation (19). In this study on subcutaneous adipose tissue, we tested several concentrations of C-peptide $(4,8$, and $16 \mathrm{nM})$ in an incubation period of $24 \mathrm{~h}$ and observed significant antilipolytic action at concentrations $\geq 8 \mathrm{nM}$. In addition to species-related differences or incubation period, anatomical depot-related differences in lipolytic activity of adipose tissues may explain the differing results. Several studies have reported that there are fat depot-related differences with regard to glucose uptake $(48,51)$, endocrine function $(38,39)$, and lipolysis $(5,44,50,55)$. The subcutaneous adipose tissue shows higher basal lipolysis than visceral fat depots. On the other hand, catecholamines-induced lipolysis is more pronounced in visceral than subcutaneous fat $(5,44,50,55)$. In addition, some antilipolytic agents including insulin and clonidine exert a more potent antilipolytic effect on subcutaneous than visceral adipocytes $(44,55)$. Therefore, the possibility that C-peptide might affect basal lipolysis in a depot-specific manner should be tested in humans by future studies. 
In addition, biological effects of C-peptide may be varied depending on the metabolic status of the body. There are some reports which suggest that certain actions of C-peptide appear only in diabetes and not in normal condition $(33,41)$. Consistent with this hypothesis, results of this study and our previous works $(19,20)$ showed that C-peptide significantly inhibited ISO-stimulated lipolysis in untreated diabetic rats, whereas it virtually had no effect on the stimulated lipolysis in insulin-treated rats and in non-diabetic subjects.

White adipose tissue secretes a large number of endocrine factors, called adipokines, such as adiponectin, leptin, resistin, and visfatin. Inappropriate secretion of adipokines is known to be involved in the development of obesity-related pathologies including atherosclerosis, diabetes, and inflammation (9). The effects of C-peptide on endocrine function of subcutaneous adipose tissue are not yet well known. Recently, Garcia-Serrano et al. (15) demonstrated that this peptide at concentrations of 1 and $10 \mathrm{nM}$ increased leptin and decreased visfatin secretion from human visceral fat. In this study, the effect of C-peptide on adiponectin secretion was investigated in human subcutaneous adipocytes. Adiponectin is a secretory protein, which promotes beta cell survival and function, decreases serum glucose by reducing hepatic glucose output, increases adipocyte number, and induces local and systemic anti-inflammatory effects (49). Decreased adiponectin level is associated with insulin resistance, metabolic syndrome, and extension of coronary artery disease $(11,54)$. Strategies to increase adiponectin have been suggested as an approach for management of adipose tissue-linked diseases, such as diabetes and insulin resistance (54). This data showed that C-peptide at $4 \mathrm{nM}$ induced a non-significant increase (approximately 32\%) in adiponectin secretion. This effect was attenuated at higher concentrations of C-peptide (8 and $16 \mathrm{nM})$, suggesting that the effect might be significant at C-peptide concentrations of $<4 \mathrm{nM}$. However, Garcia-Serrano et al. (15) reported that C-peptide at $1 \mathrm{nM}$ did not significantly alter the adiponectin secretion in visceral fat. Considering the aforementioned fat depotrelated differences, further works are suggested to elucidate the effect of lower concentrations of C-peptide on adiponectin secretion in the subcutaneous adipose tissue.

Patients with type- 1 diabetes show decreased fat mass mainly due to lack of trophic action of insulin on adipose tissue (22). The adipose mass is determined by both the number and size of adipocytes. While the dimension of adipocytes depends on the rate of lipolysis and lipogenesis, their number is controlled by a balance between generating new adipocytes (adipogenesis) and adipocyte apoptosis $(27,47)$. New adipocytes are believed to arise from resident MSCs, a process which is promoted by insulin (36). Consistent with this, this data showed that the presence of insulin in the adipogenic culture medium is essential for differentiation of MSCs into adipocytes. However, C-peptide did not induce adipogenic differentiation of MSCs and also failed to enhance the adipogenic effect of insulin. The effect of C-peptide on adipogenesis was examined only at a concentration of $16 \mathrm{nM}$, which is one limitation of this study. Nevertheless, the inability of C-peptide in inducing differentiation was also observed regarding osteogenic differentiation of MSCs which was examined at 4, 8, and $16 \mathrm{nM} \mathrm{C}$-peptide. On the other hand, C-peptide could increase proliferation of MSCs, suggesting that it may contribute to preserving an optimal pool of adipose MSCs required for adipogenesis and tissue repair. Nowadays, the abilities of adipose MSCs to proliferate and differentiate into diverse cell lineages, to migrate and home into damaged tissues, and to secrete several growth factors have made them attractive candidates for cell therapies and tissue engineering (42). However, there are some challenges that need to be resolved to increase the efficiency of stem cell therapy. One 
of the major challenges is the limited number of stem cells that can be obtained from many tissues. One approach is to incubate stem cells in vitro with pro-proliferative hormones or growth factors to generate enough numbers of cells for subsequent cell therapy (18). The stimulatory effect of C-peptide on the proliferation of adipose MSCs makes it a good choice for expanding stem cell number.

Proliferation and differentiation of MSCs are regulated by complex networks of transcription factors that control the expression of hundreds of proteins involved in survival and commitment of the cells to a certain phenotype. The two principal adipogenic factors, such as peroxisome proliferator-activated receptor- $\gamma$ (PPAR $\gamma$ ) and CCAAT/enhancer binding protein- $\alpha(\mathrm{C} / \mathrm{EBP} \alpha)$, are at the center of a network of transcription factors responsible for adipogenic differentiation of MSCs (14). On the other hand, while some transcription factors such as runt-related 2 (Runx2) and osterix are inducers of differentiation toward osteoblasts, PPAR $\gamma$ and C/EBP $\beta$ are considered as inhibitory factors for osteogenic differentiation of MSCs (13). In addition to regulating differentiation, transcription factors of the C/EBP family are of fundamental importance for controlling MSCs proliferation through interaction with proteins of the cell cycle (40). There are no sufficient data on the effects of C-peptide on the expression of transcription factors in MSCs and future studies are required in this area. Yet, in multiple cell types from multiple tissues, this peptide has been reported to stimulate several transcription factors (e.g., PPAR, Bcl-2, nuclear factor-kB, and cAMP-responsive element-binding protein) that have key roles in the control of cell processes, such as growth and apoptosis. C-peptide stimulates these factors through its own intracellular signaling or by cross talk with the insulin pathway $(23,26)$. It is rational to assume that, in diabetes, deficiency in the levels or activities of insulin and C-peptide can be accompanied by dysregulation of the aforementioned transcription factors. However, the results published in the literature are not consistent; Minteer et al. (37) reported that PPAR- $\gamma$ expression is not different between MSCs of non-diabetic and type 2 diabetic subjects, but Jumabay et al. (30) reported an increase in the expression of PPAR- $\gamma$ and $\mathrm{C} / \mathrm{EBP} \alpha$ in MSCs of type 2 diabetic rats compared with non-diabetic rats.

In conclusion, results of this study suggest that C-peptide has physiological effects in human subcutaneous adipose tissue and contributes to the regulation of basal lipolysis and pool of MSCs. Therefore, C-peptide deficiency in type-1 diabetes may be involved in dysregulation of adipose tissue functions. These results also support the current idea that coreplacement of insulin and C-peptide in diabetic patients may prevent or even ameliorate some of the diabetes-related complications.

\section{Acknowledgement}

This work was supported by a grant (911069) from Vice-Chancellor of Research and Technology, Mashhad University of Medical Sciences, Iran.

\section{Conflict of interest}

The authors declare no conflict of interest.

\section{REFERENCES}

1. Adamczak M, Wiecek A: The adipose tissue as an endocrine organ. Semin. Nephrol. 33, 2-13 (2013) 
2. Aguena M, Dalto Fanganiello R, Tissiani LAL, Ishiy FAA, Atique R, Alonso N, Passos-Bueno MR: Optimization of parameters for a more efficient use of adipose-derived stem cells in regenerative medicine therapies. Stem Cells Int. 2012, 303610 (2012)

3. Alford AI, Reddy AB, Goldstein SA, Murthy P, Tayim R, Sharma G: Two molecular weight species of thrombospondin-2 are present in bone and differentially modulated in fractured and nonfractured tibiae in a murine model of bone healing. Calcif. Tissue Int. 90, 420-428 (2012)

4. Arca M, Pigna G, Favoccia C: Mechanisms of diabetic dyslipidemia: relevance for atherogenesis. Curr. Vasc. Pharmacol. 10, 684-686 (2012)

5. Arner P: Differences in lipolysis between human subcutaneous and omental adipose tissues. Ann. Med. 27, 435-438 (1995)

6. Brandenburg D: History and diagnostic significance of C-peptide. Exp. Diabetes Res. 2008, 576862 (2008)

7. Cianfarani F, Toietta G, Di Rocco G, Cesareo E, Zambruno G, Odorisio T: Diabetes impairs adipose tissue-derived stem cell function and efficiency in promoting wound healing. Wound Repair Regen. 21, 545-553 (2013)

8. Cifarelli V, Geng X, Styche A, Lakomy M, Trucco M, Luppi P: C-peptide reduces high glucose-induced apoptosis of endothelial cells and decreases NAD(P)H-oxidase reactive oxygen species generation. Diabetologia 54, 2702-2712 (2011)

9. Coelho M, Oliveira T, Fernandes R: Biochemistry of adipose tissue: an endocrine organ. Arch. Med. Sci. 9, 191-200 (2013)

10. Ducharme NA, Bickel PE: Lipid droplets in lipogenesis and lipolysis. Endocrinology 149, 942-949 (2008)

11. Eiras S, Teijeira-Fernández E, Shamagian LG, Fernandez AL, Vazquez-Boquete A, Gonzalez-Juanatey JR: Extension of coronary artery disease is associated with increased IL-6 and decreased adiponectin gene expression in epicardial adipose tissue. Cytokine 43, 174-180 (2008)

12. Fadini GP, Albiero M, Vigili de Kreutzenberg S, Boscaro E, Cappellari R, Marescotti M, Poncina N, Agostini C, Avogaro A: Diabetes impairs stem cell and proangiogenic cell mobilization in humans. Diabetes Care 36, 943-949 (2013)

13. Fakhry M, Hamade E, Badran B, Buchet R, Magne D: Molecular mechanisms of mesenchymal stem cell differentiation towards osteoblasts. World J. Stem Cells 5, 136-148 (2013)

14. Farmer SR: Transcriptional control of adipocyte formation. Cell Metab. 4, 263-273 (2006)

15. Garcia-Serrano S, Gutiérrez-Repiso C, Gonzalo M, Garcia-Arnes J, Valdes S, Soriguer F, Perez-Valero V, Alaminos-Castillo MA, Francisco Cobos-Bravo J, Moreno-Ruiz FJ, Rodriguez-Cañete A, Rodríguez-Pacheco F, Garcia-Escobar E, García-Fuentes E: C-peptide modifies leptin and visfatin secretion in human adipose tissue. Obesity 23, 1607-1615 (2015)

16. Ghorbani A, Hadjzadeh MR, Rajaei Z, Zendehbad SB: Effects of fenugreek seeds on adipogenesis and lipolysis in normal and diabetic rat. Pak. J. Biol. Sci. 17, 523-528 (2014)

17. Ghorbani A, Jalali SA, Varedi M: Isolation of adipose tissue mesenchymal stem cells without tissue destruction: a non-enzymatic method. Tissue Cell 46, 54-58 (2014)

18. Ghorbani A, Naderi-Meshkinb H: The endocrine regulation of stem cells: physiological importance and pharmacological potentials for cell-based therapy. Curr. Stem Cell Res. Ther. 11, 19-34 (2016)

19. Ghorbani A, Omrani GH, Hadjzadeh MR, Varedi M: Effects of rat C-peptide-II on lipolysis and glucose consumption in cultured rat adipose tissue. Exp. Clin. Endocrinol. Diabetes 119, 343-347 (2011)

20. Ghorbani A, Omrani GH, Hadjzadeh MR, Varedi M: Proinsulin C-peptide inhibits lipolysis in diabetic rat adipose tissue through phosphodiestrase-3B enzyme. Horm. Metab. Res. 45, 221-225 (2013)

21. Ghorbani A, Shafiee-Nick R: Pathological consequences of C-peptide deficiency in insulin-dependent diabetes mellitus. World J. Diabetes 6, 145-150 (2015)

22. Ghorbani A, Varedi M, Hadjzadeh MR, Omrani GH: Type-1 diabetes induces depot-specific alterations in adipocyte diameter and mass of adipose tissues in the rat. Exp. Clin. Endocrinol. Diabetes 118, 442-448 (2010)

23. Grunberger G, Qiang X, Li Z, Sbrissa D, Shisheva A, Sima AA: Molecular basis for the insulinomimetic effects of C-peptide. Diabetologia 44, 1247-1257 (2001)

24. Hajer GR, van Haeften TW, Visseren FL: Adipose tissue dysfunction in obesity, diabetes, and vascular diseases. Eur. Heart J. 29, 2959-2971 (2008)

25. Hansen A, Johansson BL, Wahren J, von Bibra H: C-peptide exerts beneficial effects on myocardial blood flow and function in patients with type 1 diabetes. Diabetes 51, 3077-3082 (2002)

26. Hills CE, Brunskill NJ: C-Peptide and its intracellular signaling. Rev. Diabet. Stud. 6, 138-147 (2009) 
27. Jo J, Gavrilova O, Pack S, Jou W, Mullen S, Sumner AE, Cushman SW, Periwal V: Hypertrophy and/or hyperplasia: dynamics of adipose tissue growth. PLoS Comput. Biol. 5, e1000324 (2009)

28. Johansson BL, Borg K, Fernqvist-Forbes E, Odergren T, Remahl S, Wahren J: C-peptide improves autonomic nerve function in IDDM patients. Diabetologia 39, 687-695 (1996)

29. Johansson BL, Sundell J, Ekberg K, Jonsson C, Seppänen M, Raitakari O, Luotolahti M, Nuutila P, Wahren J, Knuuti J: C-peptide improves adenosine-induced myocardial vasodilation in type 1 diabetes patients. Am. J. Physiol. Endocrinol. Metab. 286, E14-E19 (2004)

30. Jumabay M, Moon JH, Yeerna H, Boström KI: Effect of diabetes mellitus on adipocyte-derived stem cells in rat. J. Cell Physiol. 230, 2821-2828 (2015)

31. Kersten S: Mechanisms of nutritional and hormonal regulation of lipogenesis. EMBO Rep. 2, $282-286$ (2001)

32. Klaus S: Adipose tissue as a regulator of energy balance. Curr. Drug Targets 5, 241-250 (2004)

33. Kunt T, Schneider S, Pfutzner A, Goitum K, Engelbach M, Schauf B, Beyer J, Forst T: The effect of human proinsulin C-peptide on erythrocyte deformability in patients with Type I diabetes mellitus. Diabetologia 42, 465-471 (1999)

34. Lafontan M: Adipose tissue and adipocyte dysregulation. Diabetes Metab. 40, 16-28 (2014)

35. Lafontan M, Langin D: Lipolysis and lipid mobilization in human adipose tissue. Prog. Lipid Res. 48, 275-297 (2009)

36. Lefterova MI, Lazar MA: New developments in adipogenesis. Trends Endocrinol. Metab. 20, 107-114 (2009)

37. Minteer DM, Young MT, Lin YC, Over PJ, Rubin JP, Gerlach JC, Marra KG: Analysis of type II diabetes mellitus adipose-derived stem cells for tissue engineering applications. J. Tissue Eng. 6, 2041731415579215 (2015)

38. Montague CT, Prins JB, Sanders L, Digby JE, O'Rahilly S: Depot- and sex-specific differences in human leptin mRNA expression implications for the control of regional fat distribution. Diabetes 46, 342-347 (1997)

39. Motoshima H, Wu X, Sinha MK, Hardy VE, Rosato EL, Barbot DJ, Rosato FE, Goldstein BJ: Differential regulation of adiponectin secretion from cultured human omental and subcutaneous adipocytes: effects of insulin and rosiglitazone. J. Clin. Endocrinol. Metab. 87, 5662-5667 (2002)

40. Nerlov C: The C/EBP family of transcription factors: a paradigm for interaction between gene expression and proliferation control. Trends Cell Biol. 17, 318-324 (2007)

41. Nordquist L, Moe E, Sjoquist M: The C-peptide fragment EVARQ reduces glomerular hyperfiltration in streptozotocin-induced diabetic rats. Diabetes Metab. Res. Rev. 23, 400-405 (2007)

42. Ong WK, Sugii S: Adipose-derived stem cells: fatty potentials for therapy. Int. J. Biochem. Cell Biol. 45, 1083-1086 (2013)

43. Raghupathy P: Diabetic ketoacidosis in children and adolescents. Indian J. Endocrinol. Metab. 19(Suppl. 1), S55-S57 (2015)

44. Richelsen B, Pedersen SB, Moller-Pedersen T, Bk JF: Regional differences in triglyceride breakdown in human adipose tissue: effects of catecholamines, insulin, and prostaglandin E2. Metabolism 40, 990-996 (1991)

45. Rosen ED, Spiegelman BM: Molecular regulation of adipogenesis. Annu. Rev. Cell Dev. Biol. 16, $145-171$ (2000)

46. Sato Y, Oshida Y, Han YQ, Morishita Y, Li L, Ekberg K, Jörnvall H, Wahren J: C-peptide fragments stimulate glucose utilization in diabetic rats. Cell. Mol. Life Sci. 61, 727-732 (2004)

47. Spalding KL, Arner E, Westermark PO, Bernard S, Buchholz BA, Bergmann O, Blomqvist L, Hoffstedt J, Näslund E, Britton T, Concha H, Hassan M, Rydén M, Frisén J, Arner P: Dynamics of fat cell turnover in humans. Nature 453, 783-787 (2008)

48. Stolic M, Russel A, Hutley L, Fielding G, Hay J, MacDonald G, Whitehead J, Prins J: Glucose uptake and insulin action in human adipose tissue influence of BMI, anatomical depot and body fat distribution. Int. J. Obes. Relat. Metab. Disord. 26, 17-23 (2002)

49. Turer AT, Scherer PE: Adiponectin: mechanistic insights and clinical implications. Diabetologia 55, 2319-2326 (2012)

50. Van Harmelen V, Lonnqvist F, Thorne A, Wennlund A, Large V, Reynisdottir S, Arner P: Noradrenalineinduced lipolysis in isolated mesenteric, omental and subcutaneous adipocytes from obese subjects. Int. J. Obes. Relat. Metab. Disord. 21, 972-979 (1997)

51. Virtanen KA, Lonnroth P, Parkkola R, Peltoniemi P, Asola M, Viljanen T, Tolvanen T, Knuuti J, Rönnemaa T, Huupponen R, Nuutila P: Glucose uptake and perfusion in subcutaneous and visceral adipose tissue during insulin stimulation in nonobese and obese humans. J. Clin. Endocrinol. Metab. 87, 3902-3910 (2002)

52. Wahren J, Foyt H, Daniels M, Arezzo JC: Long-acting c-peptide and neuropathy in type 1 diabetes: a 12-month clinical trial. Diabetes Care 39, 596-602 (2016) 
53. Wahren J, Larsson C: C-peptide: new findings and therapeutic possibilities. Diabetes Res. Clin. Pract. 107, 309-319 (2015)

54. Yamauchi T, Kadowaki T: Physiological and pathophysiological roles of adiponectin and adiponectin receptors in the integrated regulation of metabolic and cardiovascular diseases. Int. J. Obes. (Lond.) 32, S13-S18 (2008)

55. Zierath GR, Livingston JN, Thorne A, Bolinder J, Reynisdottir S, Lönnqvist F, Arner P: Regional difference in insulin inhibition of non-esterified fatty acid release from human adipocytes: relation to insulin receptor phosphorylation and intracellular signalling through the insulinreceptor substrate-1 pathway. Diabetologia 41, 1343-1354 (1998) 